\title{
Influence of Prenatal and Postnatal Stress on the Sexual Behavior of Rats
}

\author{
Lílian Rose Maia Gomes ${ }^{*}$, Luis Alexandre Ribeiro da Rocha ${ }^{1}$, Sonia Maria Soares Ferreira ${ }^{2}$, \\ Renata Sampaio Rodrigues Soutinho ${ }^{3}$, Euclides Maurício Trindade-Filho3\# \\ ${ }^{1}$ Department of Physiology, Alagoas State University of Health Sciences, Maceió, Brazil \\ ${ }^{2}$ Department of Stomatology and Surgery, School of Dentistry, CESMAC University Center, Maceió, Brazil \\ ${ }^{3}$ College of Biological and Health Sciences, CESMAC University Center, Maceió, Brazil \\ Email: maia.lilian@ig.com.br, luizrocha1980@hotmail.com,"emtfilho@gmail.com
}

Received 3 March 2016; accepted 3 May 2016; published 6 May 2016

Copyright (C) 2016 by authors and Scientific Research Publishing Inc.

This work is licensed under the Creative Commons Attribution International License (CC BY).

http://creativecommons.org/licenses/by/4.0/

\section{(c) (i) Open Access}

\begin{abstract}
Objective: To evaluate the effects of prenatal and postnatal stress on the sexual behavior of rats. Methods: Thirty-two 2-month-old male Wistar rats were divided as follows: the EG Group (comprised of 10 rats whose mothers underwent gestational stress), the EO Group (11 rats subjected to postnatal stress), and the SE Group (control group, comprised of 11 animals that went through no stress whatsoever). Upon reaching adulthood, these male rates were introduced to females and had their sexual behavior assessed based on the number of mounts. Results: The animals from the EP Group showed significantly fewer mounts $(74 \pm 24.77, p<0.05)$ when compared to those from the EG $(108.9 \pm 35.27)$ and SE $(99.6 \pm 20.76)$ Groups. Conclusion: The rats that underwent stress during the first days of life mated fewer times than those whose mothers were subjected to stress during pregnancy. The latter had their sexual behavior unaltered.
\end{abstract}

\section{Keywords}

Sexual Behavior, Stress, Rat

\section{Introduction}

Homosexuality has been the subject of intense philosophical and social discussions and has only recently gone through scientific scrutiny. Homosexual behavior has been ascribed to personal choice, moral deviation and unsound personal conduct, psychological, familial, social, and biological factors. However, the presence of neurobiological factors has been discussed in recent years [1]. In 1973, The North American Psychiatric Association

\footnotetext{
${ }^{*}$ Science scholarship recipient (Fapeal).

${ }^{\#}$ Corresponding author.
}

How to cite this paper: Gomes, L.R.M., da Rocha, L.A.R., Ferreira, S.M.S., Soutinho, R.S.R. and Trindade-Filho, E.M. (2016) Influence of Prenatal and Postnatal Stress on the Sexual Behavior of Rats. World Journal of Neuroscience, 6, $109-113$. 
excluded homosexuality from its Diagnostic and Statistical Manual of Mental Disorders. This removal was followed by heated discussions which culminated in the view that homosexuality was the result of a personal choice [2] [3] and was not a psychiatric disorder. This discussion goes beyond academic circles owing to the personal and social impact of the prejudice towards homosexual individuals. This prejudice can only be dealt with after the causes of homosexuality are scientifically established. Experimental studies on human homosexuality are deemed unethical, and are also very costly. We opted to use the sexual drive in rats, measured by counting the number of mounts, as a gender index of the animal. Thus, the aim of this study was to evaluate if there is any relationship between prenatal and postnatal stress and sexual behavior in rats [4].

\section{Methods}

The study was carried out after having being approved by the Alagoas State University of Health Sciences Ethics Committee (protocol 20A). Six 3-month-old female rats were mated and vaginal cytology was performed every morning to determine the beginning of gestation. The first day of gestation was established when spermatozoa were found in vaginal smears. Stress sessions were begun on the fifth day of pregnancy so as to prevent miscarriage. They went on for ten days, always from $10 \mathrm{am}$ to $12 \mathrm{pm}$. Each stress session included twenty minutes of forced swimming in a water tank $150 \mathrm{~cm}$ in diameter and $75 \mathrm{~cm}$ deep. After birth 10 male rats were selected as part of the EG group.

The EP group comprised 11 male animals whose mothers had not been stressed during gestation. These animals underwent postnatal stress sessions. Each session consisted of keeping the animals apart from their mothers for three hours daily during their first 10 days of life. Finally, the SE group had 11 male rats which had not gone through any stress whatsoever.

Upon turning two-month-old, age who presents sexual maturity, they were observed for ten hours on 10 consecutive days to assess their sexual behavior. Each males hared a cage with two female rats. A camcorder (JVC, model AX710) was used to record images from 8 am to $6 \mathrm{pm}$. At night the males were separated from the females and placed into individual cages. The procedures for the three groups were carried out simultaneously. The same researcher (LARR) was in charge of counting the number of mounts for all the animals and he was blind as to which group each animal belonged to.

Mating frequency was compared between each experimental group and the control group using the Student's t-test, deemed significant for $\mathrm{p}<0.05$. The data were analyzed using the statistical software BioEstat5.0.

\section{Results}

The results in Table 1 show that the rats from the EP group, which had undergone postnatal stress, had a significant reduction ( $\mathrm{p}=0.02)$ in mating frequency. On the other hand, the animals whose mothers had been subjected to prenatal stress developed a sexual behavior similar to that of the animals in the control group, who had not undergone any sort of stress.

\section{Discussion}

This study indicated a marked change in the sexual behavior of rats that had undergone stress during the first ten days of life, when comparing them to the animals in the control group and to those that had suffered prenatal stress. These results were similar to the ones seen by Lucion et al. [5]. These authors demonstrated that rodents momentarily separated from their mothers right after birth showed a reduction in their adult sex drive. According to these authors, the males hardly pursue the females in heat, mate fewer times, ejaculate little semen, and produce fewer spermatozoa. But they attribute these behavioral alterations to the modifications seen in the locus coeruleus. They found a $30 \%$ reduction in the number of nervous cells within this nucleus. The authors did not examine the preoptic area in the hypothalamus. Therefore, one cannot rule out that the changes in sexual drive

Table 1. Number of mounts for animals subjected to gestational stress (EG), no stress (SE), and post-gestational stress.

\begin{tabular}{cccc}
\hline Groups & EG & SE & EP \\
\hline Mean \pm SD (n) & $108.9 \pm 35.27(10)$ & $99.6 \pm 20.76(11)$ & $74 \pm 24.77^{*}(11)$ \\
\hline
\end{tabular}

${ }^{*} \mathrm{p}<0.05$ Student t-test. 
might have been caused by alterations to this structure.

The link between the preoptic area of the hypothalamus and modification in sexual behavior has been advanced by several authors [6]-[11].

In a study with sheep, Roselli et al. observed that the size of the preoptic area and the levels of aromatase are significantly greater in males than in females. The ram is one of the animals, aside from human beings, that exhibits homosexual behavior.

In homosexual animals of this species, Roselli et al. [10] saw that the preoptic area had the same size as that found in females. Cook et al. [12] noted that a transplant of the entire preoptic area from newborn male rats to female litter mates resulted in adult male sexual behavior in the transplanted females. Working with humans, LeVay et al. [13] performed tests in dozens of brains of deceased people and discovered that the hypothalamus in homosexuals was much smaller than what was seen in heterosexuals. However, this study had its validity question due to the fact that the sample had been comprised of homosexuals afflicted with acquired immunodeficiency syndrome (AIDS), which could have been the cause of the alterations detected.

Our study also demonstrated that stress endured by pregnant rats did not affect the behavior of their offspring. These results were not unlike those observed by Hines et al. [14] in humans. In a prospective study in which data were based on maternal report, Hines et al. [14] evaluated the relationship between prenatal stress and childhood sexual behavior in a population of boys and girls. They noticed that gestational stress, unlike the results seen in some studies with rats, does not influence sexual behavior in boys and has but a small influence in the sexual behavior of girls. According to these authors, this occurs because the adrenal response to stress is lower in humans. In addition, sex differentiation in humans takes longer, which in turn makes it easier the occurrence of physiological adaptations through feedback mechanisms in order to make up for the hormonal changes caused by stress response. Corroborating this train of thought, some scholars state that several other factors influence sexual behavior, with stress playing a minor role and the gender of the siblings having the most important role [11] [15].

However, we could speculate that the type of stressor in our experiment would warrant the result achieved.

Some studies have shown that different kinds of stress strigger different hormonal responses and that forced swimming does not cause significant changes in hormonal levels. This is so because a slight decline in testosterone level happens during forced swimming, but it quickly returns to basal level right after the activity is ended [16]-[19].

Nevertheless, our understanding is that the most likely explanation for this experiment having shown that a lower number of mounts and changes in sexual behavior were only seen in animals that had undergone postnatal stress would be due to the differences in neurological differentiation and maturation found in this species. In rats, irreversible sexual differentiation within this hypothalamic nucleus occurs during the perinatal and postnatal periods. It has been demonstrated that the size and the number of neurons within the sexually dimorphic nucleus increase in male ratsright around birth, and that this continues posnatally for approximately ten days [12].

It is interesting to discuss how these results seen in animals would play out in humans. Newborns who, for some reason, had been neglected by their caretakers during the first days of life, would develop brain alterations that would have sexual repercussions later in life. We know that the cerebral areas herein mentioned are not exclusive to other animals, thus being also found in humans [20]. It is also important to highlight that important differences do exist. The brain of a just born rat is at an earlier developmental stage than that of a newborn human. Thus, at this moment, its vulnerability to external aggressions, such as a stressful event, is in theory greater than that of the neurons of a newborn baby. Contrary to this line of thought, Motta et al. [21] found consistent evidence that the lack of maternal care seems to exert psychological pressure on the newborn. They found high levels of salivary cortisol, a steroid that functions as a stress marker, in babies born to mothers that had postpartum depression.

As far as we know, attraction seems to be the result of environmental and social influences upon a neurological substrate and not the result of a deliberate choice. That is why the words "sexual preference" have little meaning when it comes to sexual orientation. There are many hypotheses to explain homosexuality, but they all lack solid supporting evidence. It is then important to underscore the need for neurobiological studies that seek to pinpoint the differences between homosexuals and heterosexuals. Long-term prospective studies are necessary to verify the existence of cause and effect involving stress, environmental and biological factors, and homosexuality. These studies may shed light on the mechanisms responsible for human homosexuality and could certainly help alleviate the suffering endured by a significant share of the human population. 


\section{Conclusion}

Our results showed that the rats that underwent stress during the first days of life mated fewer times than those whose mothers were subjected to stress during pregnancy. The latter had their sexual behavior unaltered. These results make us assume similar effects in humans. Thus we can speculate that stress during pregnancy could also lead people to develop a homosexual behavior, being necessary to carry out further studies on stress in pregnant women to confirm whether these results can be extrapolated to humans.

\section{References}

[1] Segovia, S., Guillamon, A., Cerro, M.C.R., Ortega, E., Perez-Lazo, C., Rodrigues-Zafra, M. and Beyer, C. (1999) The Development of Brain Sex Differences: A Multisignaling Process. Behavioural Brain Research, 105, 69-80. http://dx.doi.org/10.1016/S0166-4328(99)00083-2

[2] Kendler, K.S., Thornton, M.D., Gilman, S.E. and Kessler, R.C. (2000) Sexual Orientation in a U.S. National Sample of Twin and Nontwin Sibling Pairs. American Journal of Psychiatry, 157, 11. http://dx.doi.org/10.1176/appi.ajp.157.11.1843

[3] Laurenti, R. (1984) Homossexualismo e a Classificação Internacional das Doenças. Revista de Saúde Pública, 5, 346247.

[4] Reich, T., Cloninger, C.R. and Guze, S.B. (1975) The Multifactorial Model of Disease Transmission: I. Description of the Model and Its Use in Psyquiatry. British Journal of Psychiatry, 127, 1-10. http://dx.doi.org/10.1192/bjp.127.1.1

[5] Lucion, A.B., Pereira, F.M., Winkelman, E.C., Sanvitto, G.L. and Anselmo-Franci, J.A. (2003) Neonatal Handling Reduces the Number of Cells in the Locus Ceruleus of Rats. Behavioral Neuroscience, 117, 894-903. http://dx.doi.org/10.1037/0735-7044.117.5.894

[6] De Olmos, J.S., Alheid, G.F. and Beltramino, C.A. (1985) Amygdala. In: Paxinos, G., Ed., The Rat Nervous System, Vol. I, Academic Press, Sidney.

[7] Diamini, D., Ribeiro, T.M. and Setian, N. (2005) Sexo cerebral: Um caminho que começa a ser percorrido. Arquivos Brasileiros de Endocrinologia \& Metabologia, 49, 37-45. http://dx.doi.org/10.1590/s0004-27302005000100006

[8] Gorski, R.A., Gordon, J.H., Shryne, J.E. and Southam, A.M. (1978) Evidence for a Morphological Difference within the Medial Preoptic Area of the Rat Brain. Brain Research, 148, 333-346. http://dx.doi.org/10.1016/0006-8993(78)90723-0

[9] Kirn, J. and Lombroso, P.J. (1998) Development of the Cerebral Cortex: I. Sexual Dirmophism in the Brain. Journal of the American Academy of Child \& Adolescent Psychiatry, 37, 1228-1230. http://dx.doi.org/10.1097/00004583-199811000-00025

[10] Roselli, C.E., Larkin, K., Resko, A.J., Stellflug, J.N. and Stormshak, F. (2004) The Volume of a Sexually Dimorphic Nucleus in the Ovine Medial Preoptic Area/Anterior Hypothalamus Varies with Sexual Partner Preference. Endocrinology, 145, 478-483. http://dx.doi.org/10.1210/en.2003-1098

[11] Rust, J., Golombok, S., Hines, M., Johnston, K. and Golding, J., the ALSPAC Study Team (2000) The Role of Brothers and Sisters in the Gender Development of Preschool Children. Journal of Experimental Child Psychology, 77, 292303. http://dx.doi.org/10.1006/jecp.2000.2596

[12] Cooke, B., Hegstrom, C.D., Villeneuve, L.S. and Breedlove, S.M. (1998) Sexual Differentiation of the Vertebrate Brain: Principles and Mechanisms. Frontiers in Neuroendocrinology, 19, 253-286. http://dx.doi.org/10.1006/frne.1998.0171

[13] LeVay, S. (1991) A Difference in Hypothalamic Structure between Heterosexual and Homosexual Men. Science, 253, 1034-1037. http://dx.doi.org/10.1126/science.1887219

[14] Hines, M., Johnston, K.J., Golombok, S., Rust, J., Stevens, M. and Golding, J. (2002) Prenatal Stress and Gender Role Behavior in Girls and Boys: A Longitudinal, Population Study. Hormones and Behavior, 42, 126-34. http://dx.doi.org/10.1006/hbeh.2002.1814

[15] Blanchard, R. and Bogaert, A.F. (1996) Homosexuality in Men and Number of Older Brothers. The American Journal of Psychiatry, 153, 27-31. http://dx.doi.org/10.1176/ajp.153.1.27

[16] Almeida, A.S., Petenusci, S.O., Anselmo-Franci, J.A., Rosa e Silva, A.A.M. and Carvalho, T.L.L. (1998) Decreased Spermatogenic and Androgenic Testicular Functions in Adult Rats Submitted to Immobilization-Induced Stress from Prepuberty. Brazilian Journal of Medical and Biological Research, 31, 1443-1448. http://dx.doi.org/10.1590/S0100-879X1998001100013

[17] Andersen, M.L., Bignotto, M., Machado, R.B. and Tufik, S.D. (2004) Different Stress Modalities Result in Distinct Steroid Hormone Responses by Male Rats. Brazilian Journal of Medical and Biological Research, 37, 791-797. 
[18] Cumming, D.C., Wall, S.R., Quinney, H.A. and Belcastro, N.A. (1987) Decrease in Serum Testosterone Levels with Maximal Intensity Swimming Exercise in Trained Male and Female Swimmers. Endocrine Research, 13, 31-41.

[19] Siegel, R.A., Weidenfield, J., Feldman, S., Conforti, N. and Chowers, I. (1981) Neural Pathways Mediating Basal and Stress-Induced Secretion of Luteinizing Hormone, Follicle-Stimulating Hormone, and Testosterone in the Rat. Endocrinology, 108, 2302-2307. http://dx.doi.org/10.1210/endo-108-6-2302

[20] Pivetta, M. (2005) Ecos da Separação. Revista Pesquisa Fapesp, 91, 2-4; 127, 1-10.

[21] Motta, M.G., Brunstein, C., Luz, C., Perrone, S., Lucion, A.B. and Manfro, G.G. (2002) Alterações no Eixo do Estresse em bebês de Mães Deprimidas: Achados Preliminares. IX Jornada Gaúcha de Psiquiatria da Região Sul, IV Jornada Gaúcha, July 2002. 